\title{
Comparative Efficacy of dsRNA VP24, VP26, RR1 and WSV477 Gene against WSSV Infection in Penaeus monodon
}

\author{
Thaduru Goolappa Puneeth, Dharnappa Sannejal Akhila, \\ Mundanda Muthappa Dechamma, Jogisar Manjunatha Shreeharsha, \\ Santhosh Kogaluru Shivakumar and Moleyur Nagarajappa Venugopal*
}

Department of Fisheries Microbiology, Karnataka Veterinary, Animal and Fisheries Sciences University, College of Fisheries, Mangalore-575002, India

*Corresponding author:

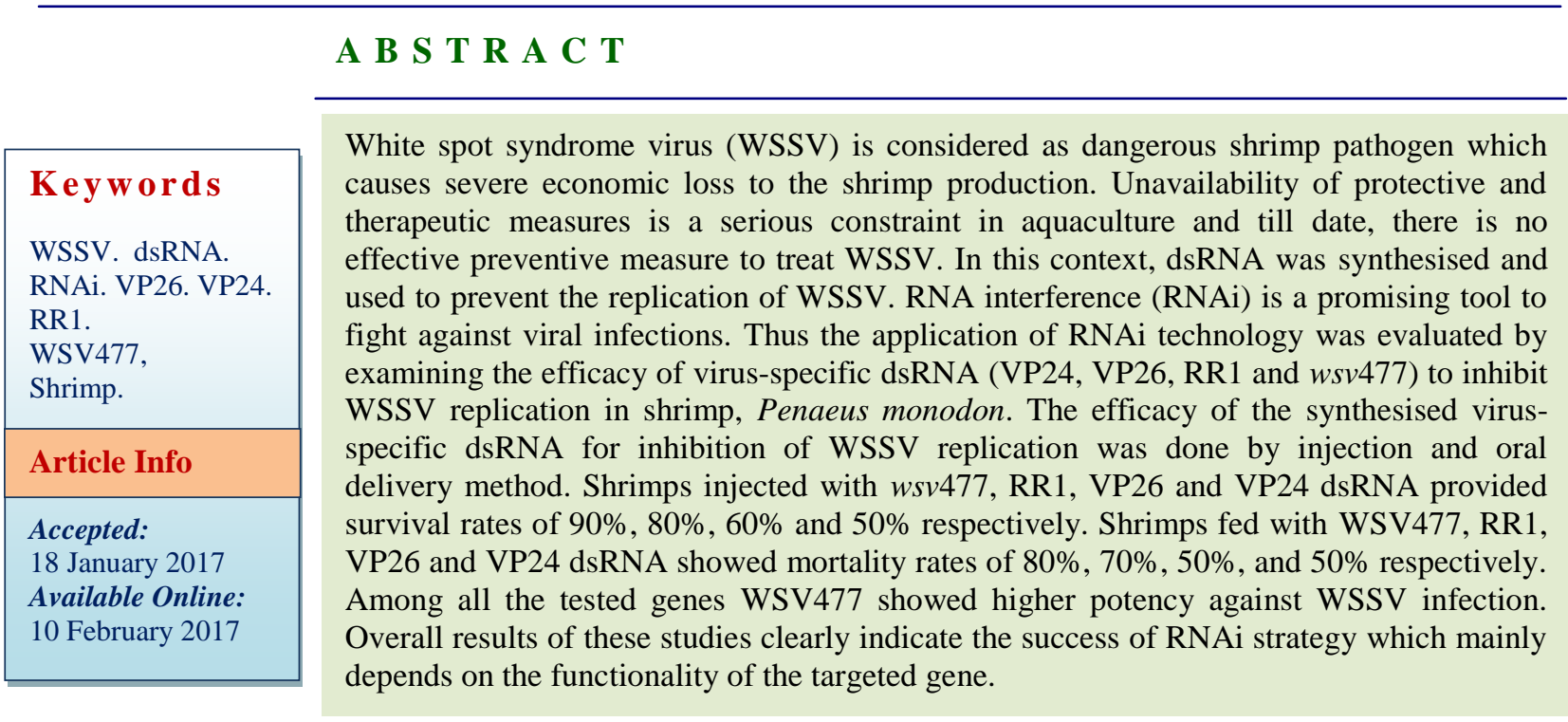

\section{Introduction}

Shrimp aquaculture is a multi-billion dollar income generating sector, contributing to the major economic growth of several countries across the world. The expansion in shrimp culture practices has also led to significant economic losses worldwide due to the viral disease outbreak. White spot disease (WSD) is caused by dsDNA virus known as the white spot syndrome virus (WSSV), considered as one of the deadly shrimp viral pathogens reported to bring about $100 \%$ mortality immediately after infection. This virus infects a wide range of aquatic crustaceans (SanchezPaz 2010). WSSV is a rod-shaped, nonoccluded, enveloped virus having tail-like appendage at one end of the virion.

As of now genome of the four WSSV isolates like Thailand $293 \mathrm{kbp}$ [WSSV-TH; Acc. No. AF369029] (van Hulten et al., 2000a; 2001a), Taiwan 307 kbp [WSSV-TW; Acc. No. AF440570] (Tsai et al., 2000a, b), China 305 kbp (WSSV-CN; Acc. No. AF332093) (Yang et al., 2001) and Korean $295 \mathrm{kbp}$ (WSSV- 
KW; Acc. No. JX515788) has been reported to be fully sequenced.

As shrimps do not possess adaptive immune system they rely solely on cellular and humoral innate immune mechanisms to fight against the invading pathogen. Hence understanding the immune system of shrimps in much detailed manner is the need of the hour to establish greater and efficient methods to control the infectious diseases and also to ensure the long-term viability of the shrimp aquaculture practices. To overcome the impacts of WSSV various therapeutic approaches are followed, that includes manipulating environmental conditions, administrating various immune modulators (Chang et al., 2003; Balasubramanian et al., 2007), vaccination (Huang et al., 2005; Jha et al., 2006), and RNA interference (RNAi) strategies (Robalino et al., 2004; Xu et al., 2007). RNAi, an evolutionary conserved natural mechanism that was initially studied in the nematode, Caenorhabditis elegans (Fire et al.1998). RNAi is a cellular process where a sequence-specificdouble-stranded RNA (dsRNA) molecule interferes with the target gene regulates the gene expression through sequence-specific silencing of target mRNA, chromatin modification, and translation repression (Robalino et al., 2005). RNAi is initiated by a dsRNA that is cleaved by RNase III enzyme (Dicer) into small interfering RNA (siRNA) of 21-23 nucleotide length that targets complementary mRNAs for degradation by an endonuclease containing RNA-induced silencing complex (RISC) (Meister and Tuschi, 2004 ).

Protection studies targeting novel genes that code for viral envelope and coat proteins are ideal due to their basic interactions inside host during the pathogen entry and proliferation (Chazal and Gerlier, 2003). Protective efficacies of various dsRNA targeting structural and nonstructural protein coding genes against WSSV infection is evidenced by several studies (Kim et al., 2007; Robalino et al., 2004, 2005;Tirasophon et al., 2005; Yodmuang et al., 2006). Structural gene VP26 is one among the major component of the virus envelope (Zhang et al., 2002; Tang et al., 2007) involved in thecytoplasmic transport of the nucleocapsid by interacting with actin or cellular actin-binding proteins (Xie and Yang 2005). VP24 is a nucleocapsid protein of WSSV that interacts with VP28 during viral infection. RR1 nonstructural protein is a large subunit of Ribonucleotide reductase enzyme that aids in nucleotide metabolism and converts ribonucleotides into deoxyribonucleotides which serve as immediate precursors of DNA (Jordan and Reichard 1998). Non-structural gene, WSV477 encodes for 208 amino acid and these peptides have GTP-binding activity (Han et al., 2007). Antisense construct on WSV477 offered potent and significant antiviral immunity against WSSV infection in comparison to other targeted envelope protein in Litopenaeus vannaemi (Akhila et al., 2015). The present study aimed at comparing the potentiality of dsRNA coding structural (VP26, VP24) and non-structural (RR1, WSV477) genes of WSSV and their possible effects against WSSV infection in Indian black tiger shrimp (Penaeus monodon).

\section{Materials and Methods}

Healthy Shrimps P. monodon, weighing 7-10 $\mathrm{g}$ were harvested from shrimp culture farm near Kumta region, Karnataka. The shrimp were acclimatised in 1000 litres capacity tanks containing filtered seawater having salinity between 20-25 parts per thousand (ppt) with constant aeration at a temperature of $28-30^{\circ} \mathrm{C}$. The commercial pelleted feed was fed to the shrimps. Salinity, temperature and dissolved oxygen (DO) were monitored regularly. The animals were screened for DNA and RNA viruses of shrimp by 
polymerase chain reaction (PCR) (Otta et al., 2003) using virus-specific primers.

\section{Preparation of viral inoculum}

Shrimps infected with WSSV having characteristic white spots were collected from the shrimp farm. The virus was isolated from gill of the WSSV infected animals using reaction protocol (Otta et al., 2003) with minor modification. The isolated virus was passed through a $0.45 \mu \mathrm{m}$ membrane filter and stored at $-80^{0} \mathrm{C}$ until future use. Virus copy number in the stock was calculated by performing the standard curve experiments using quantitative real-time PCR (data not shown). The viral inoculum is expressed as copies per microliter.

\section{Synthesis of dsRNA molecule}

In this study, bacterial expression system was used for the production of dsRNA in vivo. The structural and non-structural genes of WSSV (VP26, VP24, RR1 and WSV477) were amplified using the specific primers (Table 1). PCR amplifications was done in a thermocycler (Bio-Rad, Germany) with an initial denaturation of $95^{\circ} \mathrm{C}$ for $5 \mathrm{~min}$ followed by 30 cycles of $30 \mathrm{sec}$ denaturation at $95^{\circ} \mathrm{C}$, annealing at $55^{\circ} \mathrm{C}$ and extension at $72^{\circ} \mathrm{C}$ for $30 \mathrm{sec}$, with a final extension step of $10 \mathrm{~min}$ at $72^{\circ} \mathrm{C}$. The obtained PCR products were purified using the purification kit (Roche life science, USA) and then cloned into the pLITMUS38i vector (NEB) which is flanked by two $\mathrm{T} 7$ opposing promoters. The recombinant plasmids were transformed into an RNase III-deficient chemically competent Escherichia coli HT115 (DE3) for the production of dsRNA. The transformed colonies were screened by PCR using gene specific primers (Fig.1-4). For a starter culture, a single transformed clone was inoculated into $5 \mathrm{ml}$ of LB broth (HiMedia, Mumbai) containing $100 \mu \mathrm{g} / \mathrm{mL}$ ampicillin and $12.5 \mu \mathrm{g} / \mathrm{mL}$ tetracycline. For the bulk production of dsRNA, $1000 \mu \mathrm{l}$ of pre-culture were transferred to $100 \mathrm{~mL}$ of $\mathrm{LB}$ broth containing $100 \mu \mathrm{g} / \mathrm{mL}$ ampicillin and $12.5 \mu \mathrm{g} / \mathrm{mL}$ tetracycline. The culture was incubated at $37^{\circ} \mathrm{C}$ at $250 \mathrm{rpm}$ until the $\mathrm{OD}_{600}$ $\mathrm{nm}$ of $0.4-0.5$ was obtained and cultures were induced with $0.4 \mathrm{mM}$ isopropyl- $\beta$-Dthiogalactopyranoside (IPTG). Following induction for $4 \mathrm{hr}$, bacterial culture was harvested and extracted for dsRNA using TRIzol method according to the manufacturer's instructions. Purity and concentration of the extracted dsRNA were determined by NanoDrop 1000 spectrophotometer (Thermo Fisher Scientific, USA). The integrity of dsRNA was confirmed by digesting with RNase A (HiMedia, Mumbai) and RNase III (New England Biolabs, USA) enzymes (Fig. 5).

\section{In vivo RNAi assay in shrimp}

Protective efficacy of bacterially expressed dsRNA was determined by oral feeding and intramuscular injection to shrimp.

\section{Preparation of dsRNA feed}

Recombinant E. coli HT115 (DE3) containing different genes of WSSV were over expressed by using IPTG and inactivated in $0.5 \%$ formaldehyde for $15 \mathrm{~min}$ by incubating at $20^{\circ} \mathrm{C}$, checked for inactivation levels and stored at $4^{0} \mathrm{C}$ until further use. Following inactivation, the bacterial cells were centrifuged, washed and suspended in phosphate buffer saline (PBS) and approximately $10^{8}$ cells of the inactivated bacteria were mixed with $0.02 \mathrm{~g}$ of commercially available shrimp feeds (Charoen Pokphand, India Pvt Ltd), incubated on ice for $15 \mathrm{~min}$ and coated with cod liver oil to prevent the dispersion of bacteria in the water. The prepared feed was kept at $4^{0} \mathrm{C}$ until use. 


\section{Oral delivery}

Shrimps ( $P$. monodon) were divided into 8 groups of 10 animals each in triplicates and maintained in fibreglass troughs filled with filtered sea water at ambient temperature. Animals were fed with pelleted feed at $3.5 \%$ of body weight for 15 days as indicated in table 2. The feed coated with E. coli, HT115 (DE3) cells without vector served as host control. After 15 days, the shrimps were challenged by injecting $6 \times 10^{4}$ copies $/ \mu 1$ of WSSV, except for the negative control that was injected with PBS and fed by normal feed until completion of the experiment. The quality of water was monitored by changing the water daily. The experiment was performed up to 30 days post-challenge with WSSV.

\section{Delivery of dsRNA and WSSV challenge}

Experimental shrimps were divided into 7 groups in triplicates (experimental layout is given in table 3). Shrimps of these groups received $50 \mu \mathrm{l}$ bacterially expressed dsRNA $(2.5 \mu \mathrm{g} / \mathrm{g}$ of shrimp) intramuscularly. Following $24 \mathrm{~h}$ of dsRNA injection, the shrimps were challenged with $10^{-2}$ dilution of WSSV. At 96h of the first dose, shrimps were re-injected with abooster dose ofthesame concentration of dsRNA at the $3^{\text {rd }}$ abdominal segment of the shrimp. The positive control shrimps received PBS injection. The dsRNA from a pLITMUS38i vector without any insert served as control dsRNA experiment.

\section{Results and Discussion}

\section{Effect of dsRNA}

\section{Oral feeding}

To evaluate the ability of dsRNAs produced by $E$. coli HT115 in conferring protection against WSSV, shrimps were treated with bacterially expressed dsRNA (VP24, VP26,
RR1 and WSV477) independently. The cumulative mortality of orally fed animals is shown in figure 6 where, shrimps fed with VP26 dsRNA, VP24 dsRNA, RR1 dsRNA and WSV477 dsRNA showed cumulative mortality of $50 \%, 50 \%, 30 \%$ and $20 \%$, respectively. Whereas, positive control pLITMUS38i with $E$. coli HT115 and $E$. coli HT115 group of shrimps showed 100\% mortality on the $10^{\text {th }}$ day of post viral infection. Negative control groups showed $100 \%$ survival till the end of the experiment. Shrimp fed with WSV477 dsRNA showed survival till 45 th-day post viral infection.

\section{Injection}

Intramuscular injection of dsRNA at $2.5 \mu \mathrm{g} / \mathrm{g}$ body weight to the shrimp was found to afford the highest protection against WSSV in $P$. monodon, and the protective efficacy of the dsRNA showed varied results with the gene that was used for silencing. Shrimps treated with VP24, VP26, RR1 and wsv477 dsRNA showed a survival of $50 \%, 60 \%, 80 \%$ and $90 \%$ respectively at 15 days post viral challenge (Fig. 7). Positive control group shrimps showed $100 \%$ mortality at 10th-day post viral infection. Throughout the experimental course, no mortality was found in negative control group.

The present study aimed at documenting the protective efficacy of dsRNA targeting structural and non-structural genes of WSSV by oral and injection mode of delivery. Injection of dsRNA/ siRNA or hnRNA targetted on the specific genes was able to reduce the severity of WSD. Previous works on shrimps treated with sequence specific dsRNA that was able to provide longer days of survival 15 days post infection (dpi) in contrast to the shrimp injected with nonspecific dsRNA (Robalino et al., 2007; Sarathi et al., 2010) . Structural protein plays a vital role in the viral attachment, infection and also plays a critical role in activating host 
defence of shrimp. wsv 477 is an early gene of WSSV containing ATP/GTP-binding with GTP-binding activity which helps in regulating the expression of late genes (Sanchez-Paz 2010). Ponprateep et al., (2013) validated the interaction of $w s v 477$ protein with SPIPm2, where SPIPm2 hindered the functional property of wsv 477 which was also proved by RNAi studies. Shrimp treated with wsv477dsRNA offered higher protection compared to other targeted gene and this endorses with earlier work where antisense targeted on this gene provided $90 \%$ survival against WSSV infection (Akhila et al., 2015).

Table.1 PCR primers designed in this study

\begin{tabular}{|c|c|c|}
\hline Primers & Sequence (5'-3') & $\begin{array}{c}\text { Restriction } \\
\text { enzyme }\end{array}$ \\
\hline VP26F & CGCGGATCCATGGAATTTGGCAACCTAACAAACCT & BamHI \\
\hline VP26R & CGCAAGCTTTTACTTCTTCTTGATTTCGTCC & HindIII \\
\hline VP24F & CGCGGATCCATGCACATGTGGGGGGTTTACG & BamHI \\
\hline VP24R & CGCAAGCTTTTATTTTTCCCCAACCTTAAAC & HindIII \\
\hline RR1F & CGCGGATCCCGGACTGAGGACGCTAGAAT & BamHI \\
\hline RR1R & CGCAAGCTTCCCTCGTCCTCAAATCTTCA & HindIII \\
\hline WSV477F & CGCGGATCCATGTATATCTTCGTCGAAGG & BamHI \\
\hline WSV477R & CGCAAGCTTTTATAAGAAATGTACAATCCTATGCC & HindIII \\
\hline
\end{tabular}

Table.2 Representing the grouping of shrimps for oral delivery

\begin{tabular}{|c|l|c|}
\hline Group & \multicolumn{1}{|c|}{ Feed composition } & $\begin{array}{c}\text { No. of shrimps } / \\
\text { group }\end{array}$ \\
\hline VP26 & Feed + VP26dsRNA + PBS + cod liver oil & 10 X 3 \\
\hline VP24 & Feed + VP24dsRNA + PBS + cod liver oil & 10 X 3 \\
\hline RR1 & Feed + RR1dsRNA + PBS + cod liver oil & 10 X 3 \\
\hline wsv477 & Feed + wsv477dsrna + PBS + cod liver oil & 10 X 3 \\
\hline (E. coli HT115) & Feed + E. coli HT115 + PBS + cod liver oil & $10 \times 3$ \\
\hline (pLITMUS38i) & Feed + pLITMUS38i + PBS + cod liver oil & $10 \times 3$ \\
\hline Positive control & Feed + PBS + cod liver oil & 10 X 3 \\
\hline Negative control & Feed + PBS + cod liver oil & 10 X 3 \\
\hline
\end{tabular}

Table.3 Grouping of shrimps based on various dsRNA for injection delivery

\begin{tabular}{|c|c|}
\hline Group & No. of shrimps/ Group \\
\hline VP26dsRNA & $10 \times 3$ \\
\hline VP24dsRNA & $10 \times 3$ \\
\hline RR1dsRNA & $10 \times 3$ \\
\hline wsv477dsRNA & $10 \times 3$ \\
\hline Vector control & $10 \times 3$ \\
\hline Positive control & $10 \times 3$ \\
\hline Negative control & $10 \times 3$ \\
\hline
\end{tabular}


Fig.1 PCR amplification of VP26 gene clones by gene specific primers. Lane M: 100 bp molecular weight marker; Lane 1: Positive control;

Lane 2-4: VP26 gene positive clones

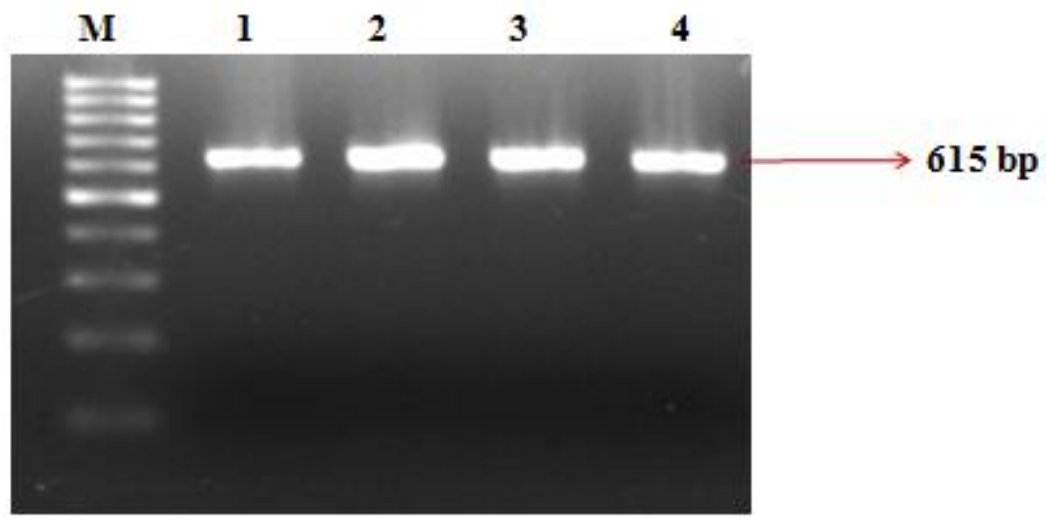

Fig.2 PCR amplification of VP24 gene clones by gene specific primers. Lane M: 100 bp molecular weight marker; Lane 1: Positive control; Lane 2: Negative control; Lanes 3- 5: VP24 gene positive clones

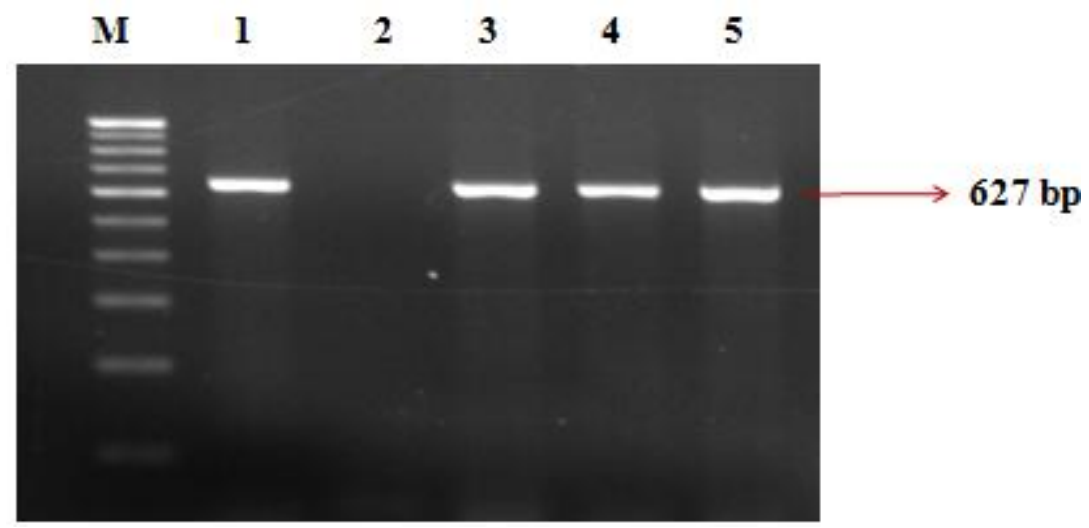

Fig.3 PCR amplification of RR1 gene clones by gene specific primers. Lane M: 100 bp molecular weight marker; Lane 1: Positive control; Lane 2: Negative control; Lanes 3- 5: RR1 gene positive clones

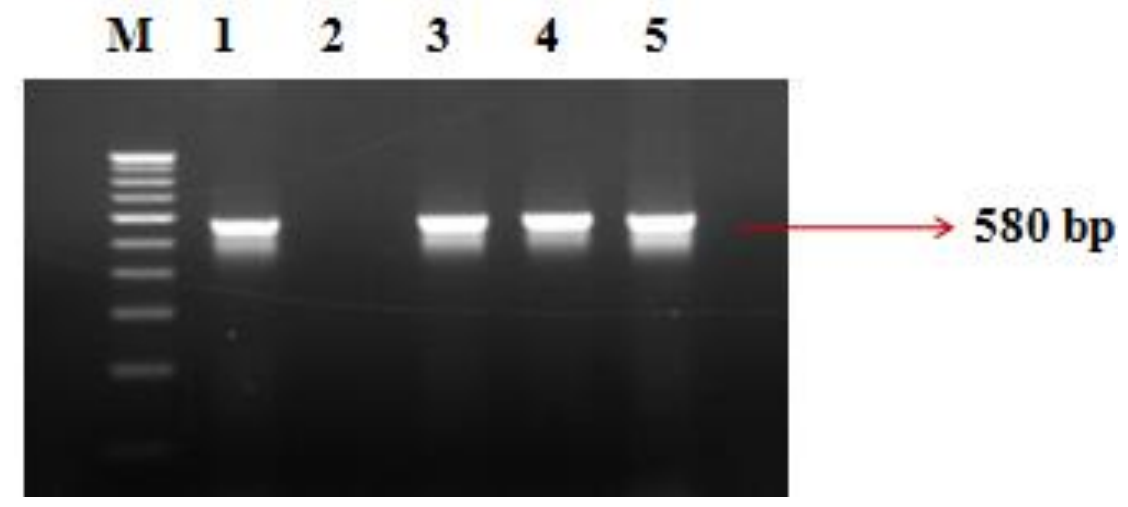


Fig.4 PCR amplification of wsv477 gene clones by gene specific primers. Lane M: 100 bp molecular weight marker; Lane 1: Positive control; Lanes 2- 5: wsv477 gene positive clones; Lane 6: Negative control

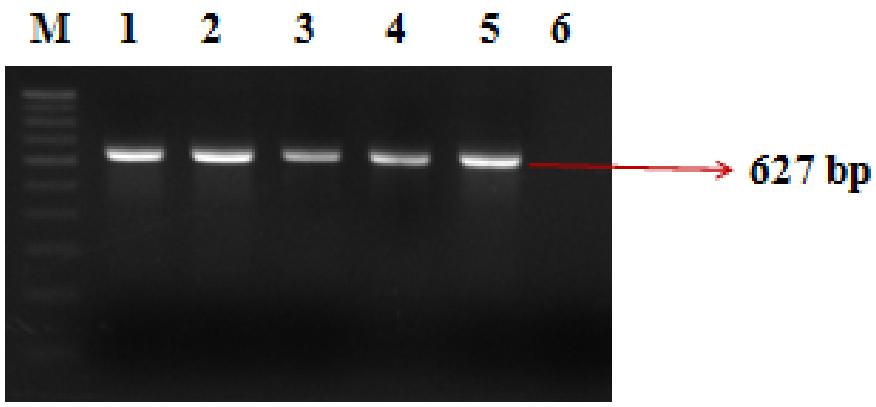

Fig.5 Verification of dsRNA integrity by RNase treatment. The integrity of dsRNA targeted to the VP26, VP24, RR1 and wsv477gene was confirmed by incubation with RNase A (Lane A) and RNase III (Lane III), which specifically digests sRNA and dsRNA, respectively. Lane M is standard DNA marker and lane $\mathrm{U}$ is untreated dsRNA

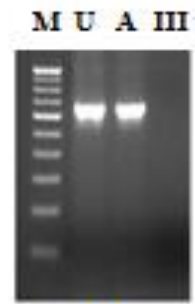

VP26

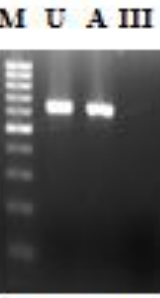

VP24

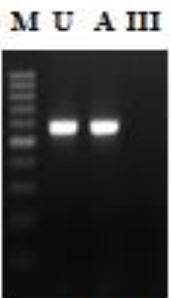

RRl

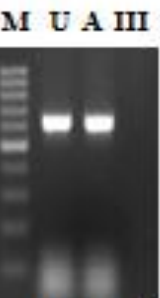

WSV477

Fig.6 Cumulative mortality of $P$. monodon orally feed with VP26, VP24, RR1 and wsv477 dsRNA

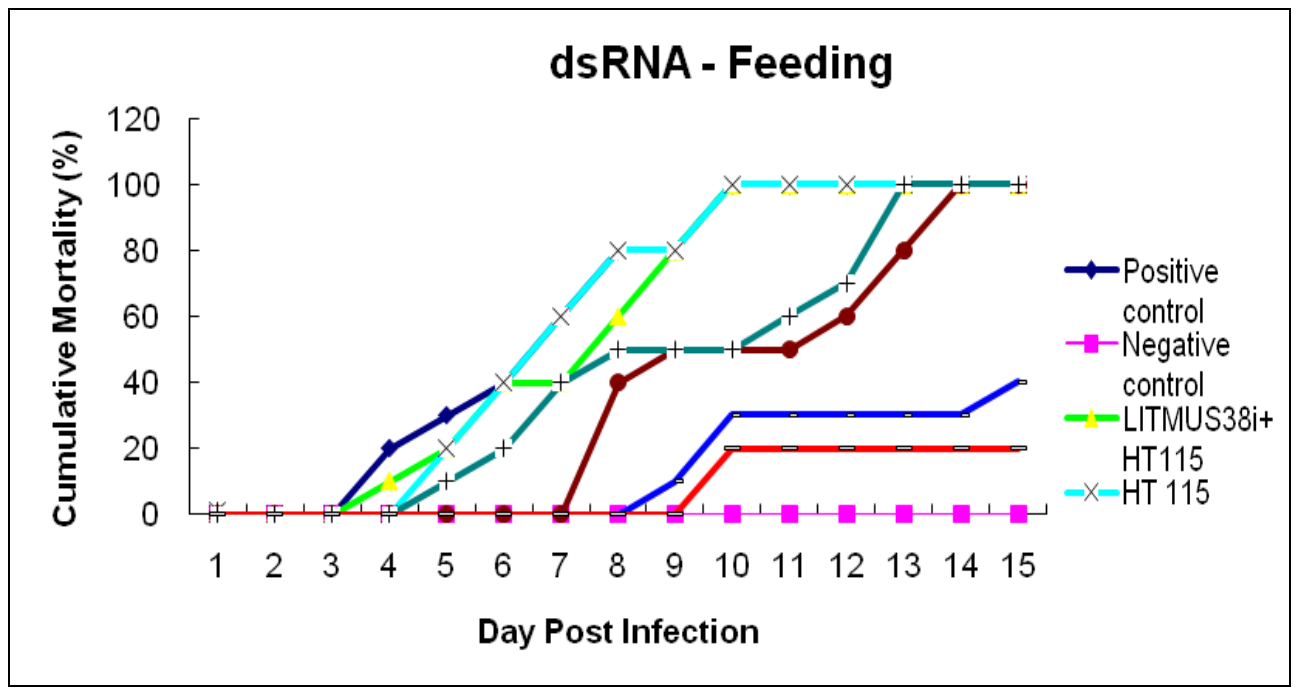


Fig.7 Cumulative mortality of P. monodon injected with VP26, VP24, RR1 and wsv477 dsRNA

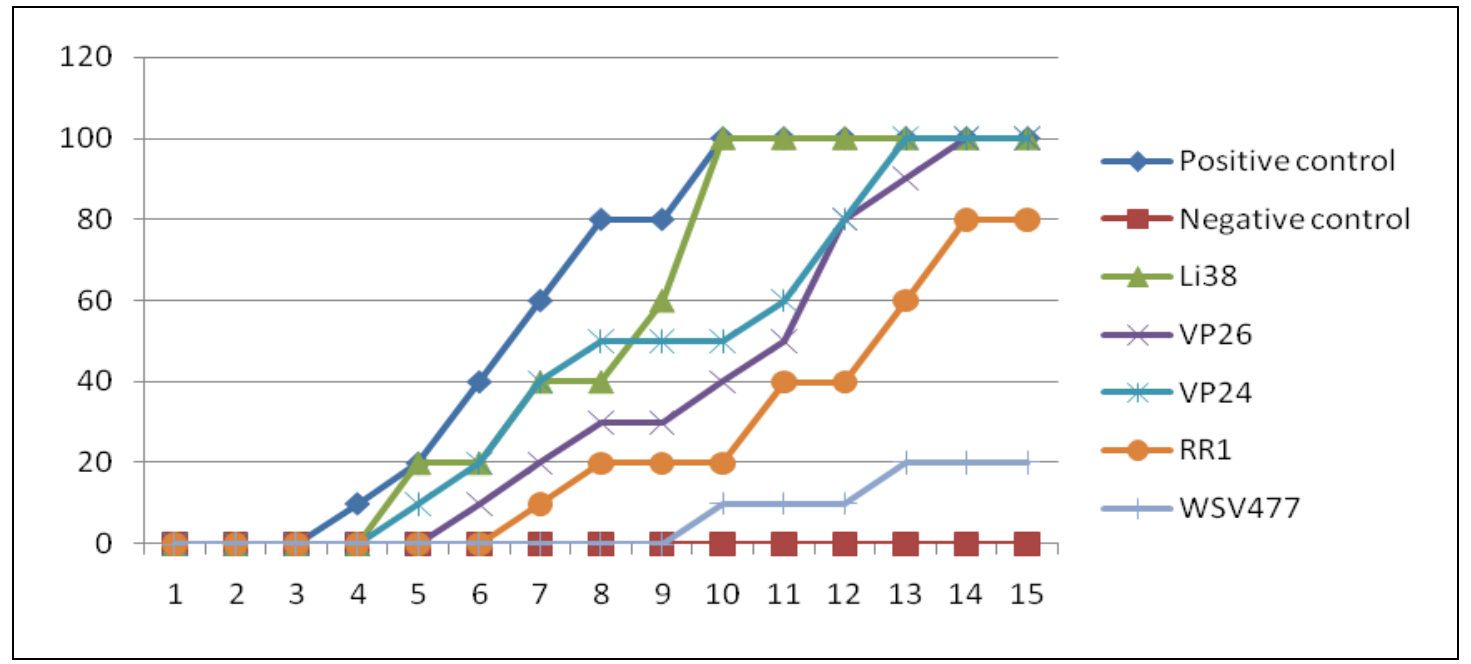

In this study, shrimp injected with wsv477dsRNA offered higher protection (90\%) compare to other targeted genes proving it to be one of the best dsRNA targets against WSSV infection.

Envelope proteins have a major role in viral infection since they are the first molecule to interact with the host (van Hulten et al., 2000, 2001a; Xie and Yang 2005). VP26 protein anchors with the nucleocapsid protein called VP51 which helps for the close attachment of envelope to nucleocapsid (Xie et al., 2005; Wan et al., 2008). P. monodon challenged with VP26 dsRNA conferred 50\% survival till the10th day of post viral infection. VP24, the chitin binding protein (Li et al., 2015) play a vital role as an anchor protein with other structural proteins viz. VP28, VP26 and WSV010. Shrimps ( $P$. monodon) challenged with VP24 dsRNA showed $40 \%$ protection till $10^{\text {th }}$-day post viral infection whereas, in L. vannamei siRNA conferred $20 \%$ survival against WSSV infection (Wu et al., 2007). In the current study shrimp treated with VP26 and VP24 dsRNA provided relatively lower survival rate in contrast to the wsv477 and RR1 protein. The potency and efficacy of dsRNA depend on the target gene and its role in the replication and pathogenesis of virus. Thus knowledge on the interaction of various structural and nonstructural proteins would help in understanding the viral morphogenesis and its infection (Chen et al., 2007) to select a better vaccine candidate against infectious WSSV disease.

In conclusion, the present study demonstrates that the intramuscular injection delivery of dsRNA targeting structural and non-structural genes can provide better protection than oral delivery. Even though oral delivery has proven to be the best preventive strategy against pathogens in shrimp aquaculture, dsRNA was injected to shrimp to evaluate the potential of virus-specific dsRNA to inhibit viral replication. Similarly, non-structural proteins confer resistance to thepathogen in comparison with structural protein in terms of survival. These results provide valuable information on developing a novel strategy of RNAi-based therapeutics in shrimp farming against White spot disease.

\section{Acknowledgement}

We are grateful to the financial support from the Indian Council of Agricultural Research (ICAR), through the national fund for basic, strategic and frontier application research in agriculture (NFBS-FARA) project (NFBSFARA/BS-3016/20122013), Government of India is greatly acknowledged.

\section{References}

Akhila, D.S., Madhu, K.M., Rai, P., Condon, K., Owens, L., Karunasagar, I. 2015. Antisense RNA- mediated protection from white 
spot syndrome virus (WSSV) infection in Pacific white shrimp Litopenaeus vannamei. Aquaculture, 435: 306-309.

Balasubramanian, G., Sarathi, M., Kumar, S.R., Sahul-Hameed, A.S. 2007. Screening the antiviral activity of Indian medicinal plants against white spot syndrome virus in shrimp. Aquaculture, 263: 15-19.

Chang, C.F., Su, M.S., Chen, H.Y., Liao, I.C. 2003. Dietary beta-1,3-glucan effectively improves immunity and survival of Penaeus monodon challenged with white spot syndrome virus. Fish Shellfish Immunol., 15(4): 297-310.

Chazal, N., Gerlier, D. 2003. Virus entry, assembly, budding, and membrane rafts. Microbiol. Mol. Biol. Rev., 67: 226-237.

Chen, J., Li, Z., Hew, C.L. 2007. Characterization of a novel envelope protein $w s v 010$ of shrimp white spot syndrome virus and its interaction with a major viral structural protein VP24. Virol., 364(1): 208-213

Chiu, W.L., Chang, W. 2002. Vaccinia virus J1R protein: a viral membrane protein that is essential for virion morphogenesis. $J$. Virol., 76: 9575-9587.

Fire, A., Xu, S.Q., Montgomery, M.K., Kostas, M.K., Driver, S.E., Mello, C.C. 1998. Potent of specific genetic interference by double-stranded RNA in Caenorhabditis elegans. Nature, 391: 806-11.

Han, F., Xu, J., Zhang, X. 2007. Characterization of an early gene (wsv477) from shrimp white spot syndrome virus (WSSV) Virus Genes, 34: 193-198.

Huang, R., Xie, Y., Zhang, J., Shi, Z. 2005 A novel envelope protein involved in white spot syndrome virus infection. J. Gen. Virol., 86(5): 1357-1361.

Jha, R.K., Xu, Z.R., Pandey, A. 2006. Protection of Procambarus clarkia against white spot syndrome virus using recombinant subunit injection vaccine expressed in Pichia pastoris. Fish Sci., 72: 1011-1019.

Jordan, A., Reichard, P. 1998. Ribonucleotide reductases. Annu. Rev. Biochem., 67: 71-98.

Kim, C.S., Kosuke, Z., Nam, Y.K., Kim, S.K., Kim, K.H. 2007. Protection of shrimp (Penaeus chinensis) against white spot syndrome virus (WSSV) challenge by double-stranded RNA. Fish \& shellfish immunol., $\quad 23(1): \quad 242-246$. doi:10.1016/j.fsi.2006.10.012

Li, Z., Li, F., Han, Y., Xu, L., Yang, F. 2015. VP24 is a chitin-binding protein involved in white spot syndrome virus infection. $J$. Virol., doi:10.1128/JVI.02357-15

Meister, G., Tuschl, T. 2004. Mechanisms of gene silencing by double-stranded RNA. Nature, 431: 343-349

Otta, S.K., Karunasagar, I., Karunasagar, I. 2003. Detection of monodon baculovirus and white spot syndrome virus in apparently healthy Penaeus monodon post larvae from India by polymerase chain reaction. Aquaculture, 220: 59-67.

Robalino, J., Bartlett, T., Shepard, E., Prior, S., Jaramillo, G., Scura, E., Chapman, R.W., Gross, P.S., Browdy, C.L., Warr, G.W. 2005. Double-stranded RNA induces sequence-specific antiviral silencing in addition to nonspecific immunity in a marine shrimp: convergence of RNA interference and innate immunity in the invertebrate antiviral response? J. Virol., 79(21): 13561-13571. doi:10.1128/JVI. 79.21 .1356113571 .2005

Robalino, J., Bartlett, T.C., Chapman, R.W., Gross, P.S., Browdy, C.L., Warr, G.W. 2007. Double- stranded RNA and antiviral immunity in marine shrimp: inducible host mechanisms and evidence for the evolution of viral counter-responses. Dev. Comp. Immunol., $\quad 31(6)$ : 539-547. doi:10.1016/j.dci.2006.08.011

Robalino, J., Browdy, C.L., Prior, S., Metz, A., Parnell, P., Gross, P., Warr, G. 2004. Induction of antiviral immunity by doublestranded RNA in a marine invertebrate. $J$. Virol., $78(19)$ : 10442-10448. doi:10. 1128/JVI.78.19.10442-10448.2004

Sanchez-Paz, A. 2010. White spot syndrome virus: an overview on an emergent concern. Vet. Res., 41(6): 43. doi:10.1051/vetres/2010015

Sarathi, M., Simon, M.C., Venkatesan, C., Thomas, J., Ravi, M., Madan, N., Thiyagarajan, S., Sahul Hameed, A.S. 2010. Efficacy of bacterially expressed dsRNA specific to different structural genes of white spot syndrome virus (WSSV) in protection of shrimp from WSSV infection. 
J. Fish Dis., 33: 603-607.

Tang, X., Wu, J., Sivaraman, J., Hew, C.L. 2007. Crystal structures of major envelope proteins VP26 and VP28 from white spot syndrome virus shed light on their evolutionary relationship. J. Virol., 81: 6709-6717.

Tirasophon, W., Roshorm, Y., Panyim, S. 2005. Silencing of yellow head virus replication in penaeid shrimp cells by dsRNA. Biochem. Biophys. Res. Commun., 334: 102-107.

Tsai, M.F., Lo, C.F., van Hulten, M.C., Tzeng, H.F., Chou, C.M., Huang, C.J., Wang, C.H., Lin, J.Y., Vlak, J.M., Kou, G.H. 2000. Transcriptional analysis of the ribonucleotide reductase genes of shrimp white spot syndrome virus. Virol., 277(1): 92-99. doi:10.1006/viro. 2000.0596

Tsai, M.F., Yu, H.T., Tzeng, H.F., Leu, J.H., Chou, C.M., Huang, C.J., Wang, C.H., Lin, J.Y., Kou, G.H., Lo, C.F. 2000 b. Identification and characterization of a shrimp white spot syndrome virus (WSSV) gene that encodes a novel chimeric polypeptide of cellular-type thymidine kinase and thymidylate kinase. Virol., 277: 100-110.

van Hulten, M.C., Tsai, w., Schipper, M.F., Lo, C.A., Kou, C.F., Vlak, J.M. 2000a. Analysis of a genomic segment of white spot syndrome virus of shrimp containing ribonucleotide reductase genes and repeat regions. J. Virol., 81: 307-316.

vanHulten, M.C., Witteveldt, J., Peters, S., Kloosterboer, N., Tarchini, R., Fiers, M., Sandbrink, H., Lankhorst, R.K., Vlak, J.M. 2001. The white spot syndrome virus DNA genome sequence. Virol., 286(1): 7-22. doi:10.1006/viro.2001.1002

vanHulten, M.C.W., Westenberg, M., Goodall,
S.D., Vlak, J.M. 2000. Identification of two major virion protein genes of white spot syndrome virus of shrimp. Virol., 266: 227236.

Wan, Q., Xu, L., Yang, F. 2008. VP26 of white spot syndrome virus function as a linker protein between the envelope and nucleocapsid of virions by binding with VP51. J. Virol., 82: 12598-601.

Wu, J., Lin, Q., Lim, T.K., Liu, T., Hew, C.L. 2007. White spot syndrome virus proteins and differentially expressed host proteins identified in shrimp epithelium by shotgun proteomics and cleavable isotope-coded affinity tag. J. Virol., 81(21): 1168111689.

Xie, X., Yang, F. 2005. Interaction of white spot syndrome virus vp26 protein with actin. Virol., 336: 93-99.

Xu, J., Han, F., Zhang, X. 2007. Silencing shrimp white spot syndrome virus (WSSV) genes by siRNA. Antivir. Res., 73(2): 126-131. doi:10.1016/j.antiviral.2006.08.007

Yang, F., He, J., Lin, X., Li, Q., Pan, D., Zhang, $\mathrm{X} ., \mathrm{Xu}, \mathrm{X}$. 2001. Complete genome sequence of the shrimp white spot bacilliform virus. J. Virol., 75(23): 1181111820. doi:10.1128/ JVI.75.23. 11811 11820.2001

Yodmuang, S., Tirasophon, W., Roshorm, Y., Chinnirunvong, W., Panyim, S. 2006. YHV-protease dsRNA inhibits YHV replication in Penaeusmonodon and prevents mortality. Biochem. Biophys. Res. Commun., 341: 351-356.

Zhang, X., Huang, C., Xu, X., Hew, C.L. 2002. Identification and localisation of a prawn white spot syndrome virus gene that encodes an envelope protein. J. Gen. Virol., 83(Pt 5):1069-1074.

\section{How to cite this article:}

Thaduru Goolappa Puneeth, Dharnappa Sannejal Akhila, Mundanda Muthappa Dechamma, Jogisar Manjunatha Shreeharsha, Santhosh Kogaluru Shivakumar and Moleyur Nagarajappa Venugopal. 2017. Comparative Efficacy of dsRNA VP24, VP26, RR1 and WSV477 Gene against WSSV Infection in Penaeus monodon. Int.J.Curr.Microbiol.App.Sci. 6(2): 665-674.

doi: http://dx.doi.org/10.20546/ijcmas.2017.602.075 